\title{
Employee's performance affected by the alignment of interest and capacity building
}

DOI: 10.35530/IT.071.05.1718

\section{ABSTRACT - REZUMAT}

\section{Employee's performance affected by the alignment of interest and capacity building}

This study emphasizes the factors that may lead to increase the employee performance in the textile sector in Pakistan. The study observes an impact of capacity building, alignment of interest and manager support in employee performance through the moderating role of employee retention.

The approach consists in survey questionnaire used to collect data. Data was analysed through SPSS 23 and Smart-PLS 3. The results indicate that manager support, capacity building and the alignment of interest have a noteworthy influence on employee performance. Additionally, if employee retention is considered as a moderator then the overall impact would be more significant to employee performance.

According to these results, capacity building, manager support and alignment of interest contribute positively to employee's performance. The results encourage the managers to invest in training their employees to improve their organizational performance/productivity as well as to consider the alignment of interest as a tactical and operational strategy to retain their key employees.

Keywords: manager support, alignment of interest, capacity building, employee retention, employee performance, Pakistan

\section{Performanța angajaților influențată de alinierea interesului și consolidarea capacității}

Acest studiu identifică factorii care pot duce la creșterea performanței angajaților în sectorul textil din Pakistan. Studiul observă un impact al consolidării capacităților, aliniării interesului și sprijinului managerilor asupra performanței angajaților, prin rolul moderator al fidelizării angajaților.

Abordarea constă în aplicarea chestionarului pentru colectarea datelor. Datele au fost analizate prin SPSS 23 și Smart-PLS 3.

Rezultatele indică faptul că sprijinul managerilor, consolidarea capacităților și alinierea intereselor au o influență remarcabilă asupra performanței angajaților. În plus, dacă fidelizarea angajaților este considerată un moderator, atunci impactul general ar fi semnificativ pentru performanța angajaților.

Conform acestor rezultate, consolidarea capacităților, sprijinul managerilor și alinierea interesului contribuie pozitiv la performanța angajaților. Rezultatele îi încurajează pe manageri să investească în instruirea angajaților lor pentru a-și îmbunătăți performanța organizațională/productivitatea, precum și să ia în considerare alinierea intereselor ca o strategie tactică și operațională pentru a-și păstra angajații cheie.

Cuvinte-cheie: sprijin managerial, alinierea intereselor, consolidarea capacităților, fidelizarea angajaților, performanța angajaților, Pakistan

\section{INTRODUCTION}

Capacity development is essential to improve employee performance. Recently, the Pakistan textile industry explored the effect of capacity building, manager support and alignment of interest on employee performance and productivity. Currently, this activity has focused on key employees only but we consider that it will include the operational level soon.

The survey helps to understand the effect of capacity building, manager support and alignment of interest on retention of employees and their performance in the textile sector. The impact of capacity building shouldn't be ignored because it helps to understand the job and culture of the organization. Researchers depicted that employees from different backgrounds have their expertise so that organizations should establish training programs to introduce their own culture to employees. In this way employees can perform the job as they are required. It may lead positive impact on employees and consequently employee's retention [1]. Capacity building is the enhancement of knowledge, proficiency and behaviour of individual and group of people that contributes in design, development, management and maintenance of institutional and operational infrastructures and processes that are locally important [2].

Employee satisfaction is imagined as one of the competitive advantages. If employees would be satisfied then they would work better and devoted their full attention to the achievement of organization's goals. 
Corporate success depends on the efficiency of employees [3]. Employee satisfaction and retention are considered as one of the key competitive advantage for the business. In this context, researchers postulate that through alignment of interest, an organization must introduce training programs to enhance employee's knowledge and skills to fulfil the aims of the organization [4]. Researchers conclude that manager's trust over subordinates creates a positive impact on employee performance. This study emphasizes that employee performance and retention are key factors for the reputation of the company so that the company should include these factors while elaborating the corporate strategy.

\section{LITERATURE REVIEW}

\section{Employee performance}

An organization hires individual to perform a specific job and the work results are gathered in performance [5]. According to Mathis, performance includes the punctuality of employees as well as the effectiveness and efficiency of the individual for required output in the given input [6]. Job appraisal and expertise can be seen as a positive emotion in an individual's status and it is regarded as an employee's performance [7]. Sempane et al. postulate that employee performance comprises an employee's overall assessment and appraisal of the work environment [8]. The organization's goal can be affected by an individual's efficiency [3]. Employee's performance subject to the performance management strategy adopted by the organization [9]. Performance measures such as job participation, empowerment, job satisfaction, job flexibility, employee training programs and appraisal and reward system affect the organization's performance [10]. There are many external and internal factors that impact employee's performance. According to this study manager support, capacity building and alignment of interest are key factors that effect on employee's performance.

\section{Manager support}

Employee encourages flexibility of work, rewards and suggestions on a specific assignment. Manager support improves employee's confidence over the job. Manager support develops the consistency between employee's performance and the organization's goals [11-12]. Former research concludes that participative leadership may or may not be lead to employee's satisfaction and performance [13]. In order to maintain confidence over employees, the manager should have good and direct contact with them [14]. A manager knows how to motivate employees by providing a decent work state and boost morale. In this way, they can accept more challenges and willing to maintain a positive image of learning, development and success [15]. The individual performance of employees can be achieved through unbiased appraisal against the performance levels set by their managers continuously [16]. The flexibility of work means that the manager refers to the employees in their work and supports them in all the issues that come across during the work. Many managers recognize that they lack social management skills [17]. Many organizations lack levels of non-technical training. Managers use power to ensure organizational goals through organizational dynamics. Organizations summarize the importance of power in the following way: "Energy is a central conception in physics and power is one of the central concept in the social sciences" [18].

$\mathbf{H}_{\mathbf{1}}$ : Manager support has a positive influence on performance of employee.

\section{Capacity building}

Capacity building will enhance the productivity of employees. Consequently, they get the desired output and benefits to the organization also. Hughes explains capacity building as factors contributing to the development of the learning environment for individuals [11]. Capacity building supports teamwork and employee motivation. In this way, the resources can be utilized properly and it will help to enhance the development of resources and group efficiency. Capacity building is a vast term used in corporate strategy [19]. Capacity building refers to the enhancement of the capability of an organization to carry out operations to achieve goals. According to Al-Roubaie, skill building is not merely helps to boost up the physical infrastructure and human capital but also gives new directions for research and development [20]. For effective and efficient performance, managers must recognize every employee's strength then they would pay more attention and achieve organizational goals with loyalty.

$\mathbf{H}_{2}$ : The capacity building has a positive and significant influence on employee's performance.

\section{Alignment of interest}

Alignment of interest is considered as one of the important elements of corporate governance. According to researchers, in the presence of support schemes and policies individuals get satisfied and enable to deliver desired results to the employer. On the other hand, if there is no support employees will not be satisfied [21]. Researchers assert that alignment of interest between employee and employer may result in employee satisfaction and consequently employee retention [22-26]. Specialists postulate that we need to comprehend the relationship between employee's perception and employer's strategy so that we may conclude the employee's behaviour towards corporate strategy offering to them. According to these researcher's alignment of interest has a significant impact on individual performance so HRM should focus the alignment of interest [22, 24]. Alignment of interest is not merely used as a performance measure, but also for employee's satisfaction and reduces the turnover of the organization. In this context, Wright et al. expresses that alignment of interest 
is not simply a performance measure but it shows the relationship and the level of contribution of an employee to corporate strategy [27]. It also can be used to enhance the contribution of an employee in achieving organizational goals. Organization's and employee's goals should be in line to achieve employee dedication and better performance as well [28].

$\mathbf{H}_{3}$ : The alignment of interest has a positive and significant influence on performance of employee.

\section{Employee retention}

Retention of staff is a good sign for the organization and it will help companies to redesign their policies regarding employees. Employee commitment can be achieved by challenging tasks. The significant task can increase the interest of employees and employee retention [29]. There is a strong relationship between job gratification and employee's turnover, so organizations must introduce staff motivational programs fo retention of key employees [30]. Cappelli asserts the factors that have a direct relationship between organization strategy and employee's retention: organization reputation, progress opportunities, internal environment, work duration, organization's attitude and termination policy [31]. Job devotion and loyalty are related to employees' sense of value and pride [32]. The studies conclude that the key factors of employee retention are: merit orientation, training opportunity, remuneration and safety, work sovereignty, reward and promotion [33]. Level of attachment of employee with organization dictates the performance of the organization, level of absence and retaining of key employees [34]. Professional and training programs should be introduced to upsurge the abilities of employees and induce them for productive results [35]. If employers have confidence over employees and understand the feelings and ideas with the receptive bent of mind, then it will increase devotion and faithfulness [36].

Our study focused on employee performance as a dependent value indicator, considering that the best performers have more information, expertise and competence, which is essential contribution to the organization success. We used employee retention as a moderator. Therefore, the moderation variable has a large effect on the relationship between the independent variables and the dependent variables.

$\mathbf{H}_{4}$ : Employee retention plays a moderating role with the relationship between managers' support and employee performance.

$\mathbf{H}_{5}$ : Employee retention plays a moderating role with the relationship between capacity building and employee performance.

$\mathbf{H}_{6}$ : Employee retention plays a moderating role with the relationship between the alignment of interest and employee performance.

\section{THEORETICAL FRAMEWORK}

Capacity development, alignment of interest and retention of employees are key factors to improve the

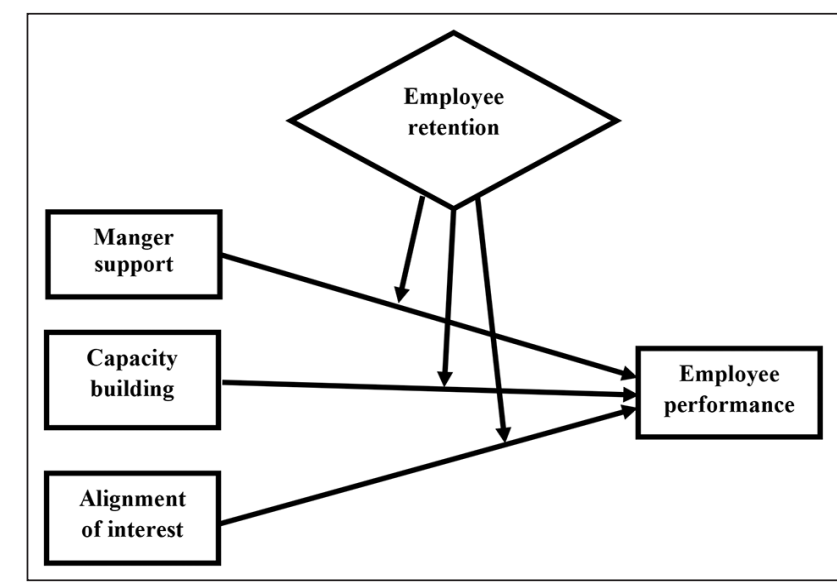

Fig. 1. Theoretical framework of this study

performance of employees in the textile sector. We have structured the theoretical framework to describe the relationship between management support, alignment of interest, skill development and employee's performance in the presence of employee retention as a moderator (figure 1). Alignments of interest, capacity building and manager support have a positive relationship on employee performance. The change in alignment of interest, capacity building, and manager support will impact employee performance.

\section{METHODOLOGY}

The method contains data on research design, population, sampling, composition, reliability of a questionnaire and data collection along with valuation procedures. The collected data was analysed to determine the results. The effect of capacity building, manager support, alignment of interest and employee retention on employee performance is examined in the context of the textile sector. The quantitative approach that grounded on primary data has been used to study and investigate the subject matter for research. The population in this inquiry consists of lower to top-level that are performing their duties in the textile sector of Faisalabad, Pakistan. The technique that has been used for data collection is convenient sampling. 250 questionnaires were distributed, 200 questionnaires were collected from the respondents. Out of 250 , fifty questionnaires were unconfined and were not suitable for interpretation of results. Statistical analysis was applied to the rest of the 200 questionnaires. The adaptive approach has been used for the questionnaires; a structured questionnaire drawn on a five-point Likert scale ranging from " 5 " indicating a strong agreement with the " 1 " statement indicates Strong disagreement with the statement. The selected questions were based on the prior good reliabilities in Pakistan and other countries. The questions reference is presented in table 1. In the study, the causal melding approach and descriptive analysis by Smart PLS (Partial Least Squares) and SPSS (Statistical Package of Social Sciences) were applied. 
Table 1

\begin{tabular}{|c|l|c|c|}
\hline \multicolumn{4}{|c|}{ THE QUESTION REFERENCE } \\
\hline No. & \multicolumn{1}{|c|}{ Construct } & Items & $\begin{array}{c}\text { Cronbach's } \\
\text { alpha }\end{array}$ \\
\hline 1 & Manager support [37] & 12 & 0.80 \\
\hline 2 & Capacity building [38] & 12 & 0.86 \\
\hline 3 & Alignment of interest [39] & 4 & 0.82 \\
\hline 4 & Employee retention [40] & 5 & 0.88 \\
\hline 5 & Employee performance [41] & 8 & 0.77 \\
\hline
\end{tabular}

Table 2

\begin{tabular}{|c|c|c|c|c|c|}
\hline \multicolumn{6}{|c|}{ EVALUATION OF THE MEASUREMENT MODEL } \\
\hline Variables & Items & FL & AVE & CR & $\begin{array}{c}\text { Cronbach's } \\
\text { alpha }\end{array}$ \\
\hline \multirow{8}{*}{$\begin{array}{c}\text { MS/ } \\
\text { manager } \\
\text { support }\end{array}$} & MS2 & 0.928 & 0.838 & 0.976 & 0.974 \\
\hline & MS4 & 0.946 & & & \\
\hline & MS5 & 0.742 & & & \\
\hline & MS6 & 0.941 & & & \\
\hline & MS7 & 0.940 & & & \\
\hline & MS8 & 0.954 & & & \\
\hline & MS9 & 0.933 & & & \\
\hline & MS10 & 0.920 & & & \\
\hline \multirow{6}{*}{$\begin{array}{c}\text { CB/ } \\
\text { capacity } \\
\text { building }\end{array}$} & CB13 & 0.919 & 0.830 & 0.967 & 0.960 \\
\hline & CB14 & 0.958 & & & \\
\hline & CB15 & 0.909 & & & \\
\hline & CB16 & 0.942 & & & \\
\hline & CB23 & 0.770 & & & \\
\hline & CB24 & 0.953 & & & \\
\hline \multirow{3}{*}{$\begin{array}{c}\mathrm{Al} / \\
\text { alignment } \\
\text { of interest }\end{array}$} & $\mathrm{Al} 25$ & 0.922 & 0.786 & 0.916 & 0.864 \\
\hline & $\mathrm{Al} 26$ & 0.924 & & & \\
\hline & $\mathrm{Al} 27$ & 0.808 & & & \\
\hline \multirow{3}{*}{$\begin{array}{l}\text { ER/ } \\
\text { employee } \\
\text { retention }\end{array}$} & ER29 & 0.949 & 0.980 & 0.995 & 0.993 \\
\hline & ER32 & 0.946 & & & \\
\hline & ER33 & 0.956 & & & \\
\hline \multirow{4}{*}{$\begin{array}{c}\text { EP/ } \\
\text { employee } \\
\text { performance }\end{array}$} & EP34 & 0.989 & 0.903 & 0.965 & 0.947 \\
\hline & EP39 & 0.992 & & & \\
\hline & EP40 & 0.983 & & & \\
\hline & EP41 & 0.997 & & & \\
\hline
\end{tabular}

Notes: Items MS1, MS3, MS11, MS12, CB17, CB18, CB19, CB20, CB21, CB22, Al27, ER30, ER31 and EP30, EP35, EP36, EP37, EP38 were deleted to improve EP. AVE (average variance extracted); CR (composite reliability).

Table 3

DISCRIMINANT VALIDITY AT CONSTRUCT LEVEL

\begin{tabular}{|c|c|c|c|c|c|}
\hline Variables & Al & CB & MS & EP & ER \\
\hline Al & $\mathbf{0 . 8 8 6}$ & & & & \\
\hline CB & 0.072 & $\mathbf{0 . 9 1 1}$ & & & \\
\hline MS & 0.038 & -0.085 & $\mathbf{0 . 9 1 5}$ & & \\
\hline EP & 0.696 & 0.125 & 0.055 & $\mathbf{0 . 9 9 0}$ & \\
\hline ER & 0.290 & 0.019 & 0.098 & 0.335 & $\mathbf{0 . 9 5 0}$ \\
\hline
\end{tabular}

Note: The average variance's square root is extracted in the diagonals and the remaining entries are correlation values.

\section{RESULTS}

\section{Descriptive analysis}

For the study, 200 questionnaires represent the input in SPSS to perform the descriptive analysis and to discuss the demographic characteristics of respondents in the textile sector. In this study, demographic characteristics include gender, age, education, designation and experience.

\section{Model assessment}

PLS envisages the relationship between the dependent variable, independent variable and the explained variance [42]. The causal modelling approach by Smart PLS includes two phases, one is the evaluation of the outer model (measurement model) and the other is inner model (structural model) [43]. The measurement model explains the connection between constructive and linked items and the structural model elaborates the connection between exogenous and endogenous constructs [44].

\section{Assessment of measurement model (reliability and validity analysis)}

For reliability and validity, the assessment of the measurement model has been made [44]. Outer loading and composite reliability decided the reliability of the model [45]. In table 2, results show that the outer loading and composite reliability exceed the recommended value of 0.70 , which approved the model reliability at items level as well as construct level [42]. The average variance extracted (AVE) and composite reliability were used to measure the validity of the measurement model [43]. In table 2, AVE and CR are higher than the acceptable values of 0.5 and 0.7 respectively and this will offer support to convergent validity [44-45]. Cronbach's alpha is based on internal consistency and is used to assess reliability. The Cronbach's alpha is used to calculate the average of measuring constructs and its correlation. Items with the value of Cronbach's alpha which exceeds 0.5 are reliable [46]. In table 2, the values of Cronbach's alpha are greater than 0.5 .

Fornell \& Larcker's criterion is used to assess the discriminant validity, i.e. the square root of the AVE of a construct (diagonal values) should be greater than the correlations between other constructs (off-diagonal values) in row and columns. Table 3 ensures the discriminant validity at the construct level as it satisfied the given condition.

\section{Evaluation of structural model}

The substantiality of path coefficients and the amount of explained variance ( $R$ square) in endogenous constructs explain the analytical 


\begin{tabular}{|c|c|c|c|c|c|c|}
\hline \multicolumn{7}{|c|}{ EVALUATION OF THE STRUCTURAL MODEL } \\
\hline Hypothesis & Relationship & Path coefficient & SD & t-value & p-value & Observations \\
\hline H3 & Al->Performance & 0.627 & 0.058 & 10.857 & 0.000 & Supported \\
\hline H2 & CB->Performance & 0.097 & 0.059 & 2.628 & 0.040 & Supported \\
\hline H1 & MS->Performance & 0.023 & 0.078 & 0.298 & 0.766 & Not Supported \\
\hline H4 & Retention->Performance & 0.158 & 0.058 & 2.718 & 0.007 & Supported \\
\hline \multicolumn{2}{|c|}{ Moderating Effect 1->EP } & 0.038 & 0.066 & 0.582 & 0.561 & Not Supported \\
\hline \multicolumn{7}{|c|}{ Moderating Effect 2->EP } \\
Moderating Effect 3->EP & 0.116 & 0.054 & 2.152 & 0.032 & Supported \\
\hline
\end{tabular}

inspiration of the inner model [44]. Path's significance is determined by applying the PLS algorithm and bootstrapping with 5000 samples and get path coefficients and t-values [44]. Table 4 gives a detailed picture of all path coefficients, standard errors, t-values and corresponding $\mathrm{p}$-values. Moreover, the Rsquared index of the variables demonstrated a satisfactory level of predictability, which exceeded the suggested starting point of 0.1 [47]. The list of Rsquare values is given in table 5 and shown in figure 2 that is 0.526 , which is exceeding form 0.1 . Figure 2 presents the relationship between variables as per the PLS-SEM model.

Table 5

\begin{tabular}{|c|c|c|c|}
\hline \multicolumn{3}{|c|}{ THE R $R^{2}$ VALUE OF ENDOGENOUS STRUCTURAL } \\
\hline $\begin{array}{c}\text { Predictor } \\
\text { Construct }\end{array}$ & $\begin{array}{c}\text { Target } \\
\text { Construct }\end{array}$ & R-squared & $\begin{array}{c}\text { Predictive } \\
\text { Accuracy }\end{array}$ \\
\hline $\begin{array}{c}\text { MS, CB, Al } \\
\text { and ER }\end{array}$ & EP & 0.526 & Substantial \\
\hline
\end{tabular}

Moreover, the $\mathrm{R}$ square value is listed in table 5 . In the structural model, the R square's value for the con- p-value emphasis the significance of the exogenous variable on the endogenous variable. The t-value of the alignment of interest is 10.857 , which reflect its high influence on the performance of textile sector employees. Furthermore, it has a significant $p$-value 0.000 level, which is less than the ordinary value of 0.5 and confirms the hypothesis $(\mathrm{H} 3)$ is also accepted $(\beta=0.627, p<0.05, t<10.85)$.

$\mathrm{H}_{3}$ : The alignment of interest has a substantial influence on the employee performance of the textile sector.

Next, we hypothesized (H1) that manager's support positively correlates with employee performance. Figures 2 and 3 highlight the positive $\beta$ value of 0.023 but the t-value shows the non-significance effect of the independent variable on the dependent variable. This independent variable has a t-value of 0.298 that reflects its non-significance on the employee's performance in the textile sector of Pakistan. On the other hand the p-value 0.766 indicates non-significance because it is slightly above than standard value 0.05 and shows that hypothesis $\mathrm{H}_{1}$ can be ignored to some extent $(\beta=0.023, p=0.086>0.05$, $t=0.298<1.960)$.

struct is considered as low, medium and significant $0.25,0.50$ and 0.75 respectively [44]. The capacity buildings, managers' support, alignment of interest and employee retention as a moderator, are found to be significantly associated with employee performance respectively, explaining $52.6 \%$ of the variance.

Figures 2 and 3 display the results of the structural model through PLS output. First, we hypothesized (H3) that the alignment of interest has a positive and substantial effect on employee performance. In table 6 positive $\beta$ value 0.627 and the

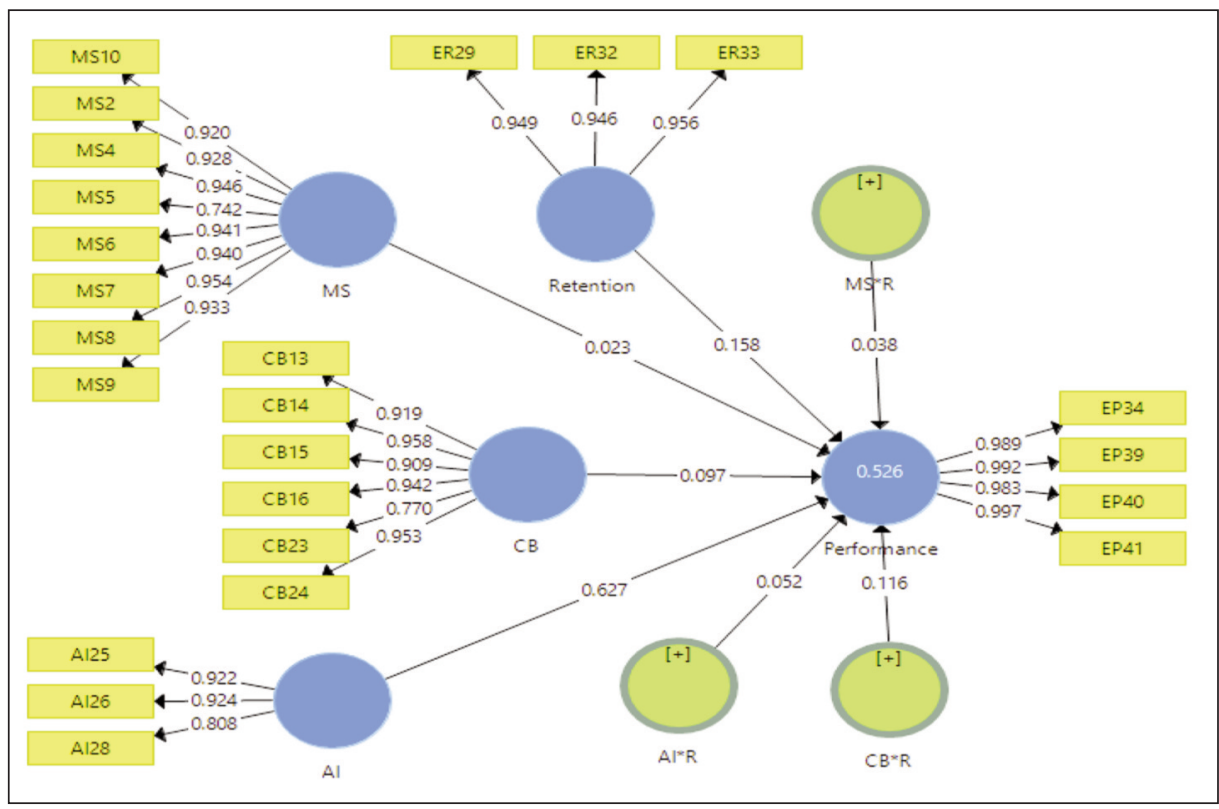

Fig. 2. PLS algorithm 


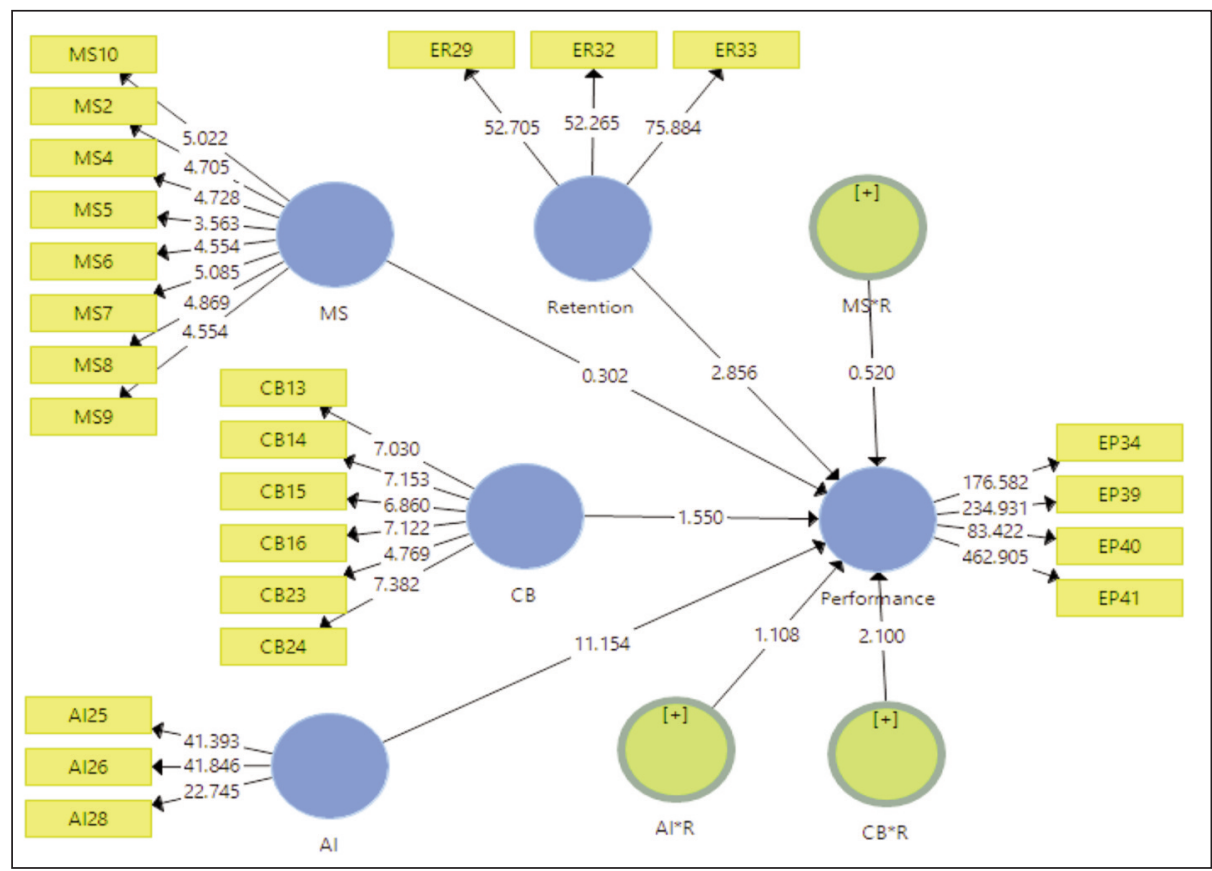

Fig. 3. Bootstrapping

\section{DISCUSSION}

As per this study, the alignment of interest and capacity building has a positive and significant effect on employee performance in the textile sector of Pakistan and contributes $63 \%$ and $20 \%$ respectively. According to prior researches, it was concluded that the intellectual capital of employees will rise with the increase in training of employees and alignment of interest. Human resource development practices can be polished by training and capacity building programs, consequently, it will affect employees' intellectual capital positively and increase

Now, the capacity building has a positive influence on employee performance as per our hypothesized (H2). In this context, table 4 highlights positive $\beta$ value 0.097 and the $p$-value $0.040<0.5$ substantiate the influence of the independent variable on the dependent variable. Furthermore, the t-value 2.628 reflects the high influence on employee performance in the textile sector. Accordingly, this hypothesis $(\mathrm{H} 2)$ is also accepted $(\beta=0.097, p<0.05, t<2.628)$. Subsequently, we hypothesized (H4) that employee retention is a moderating variable between the manager's support, capacity building, alignment of interest and employee performance.

The positive $\beta$ value 0.158 , $p$-value 0.007 and t-value confirm that employee retention has moderated the relationship of manager's support and employee performance significantly. In the presence of the moderating effect between MS and EP, the t-value of moderation effect 0.038 reflects a positive influence between two variables and the p-value 0.561 is considered insignificant. Resultantly, hypothesis $\left(\mathbf{H}_{5}\right)$ is not supported $(\beta=0.038, p>0.05, t>0.582)$. The study hypothesis that employee retention has a moderating effect on the relationship between capacity building and employee performance. In this context, we conclude that our moderate variable has a significant influence on their relationship, as it has a $\mathrm{t}$-value 2.152 and $\mathrm{p}$-value 0.032 . So, hypothesis $\left(\mathbf{H}_{6}\right)$ is also accepted by findings $(\beta=0.116, p<0.05$, $t<2$.152). Then, the findings show that employee retention plays a moderating role between the alignment of interest and employee's performance. Figure 3 indicates that $\beta$ value is $0.052, p=0.006$ and $\mathrm{t}$-value $=2.114$ show that employee retention has moderated the relationship of alignment of interest and employee performance significantly. productivity and performance at work [48-49]. This relationship ultimately contributes to the organizational performance. Generally, employee retention and employee satisfaction can be achieved through training, development and capacity building [50]. The scope of capacity in individual skills includes program design, education and training to fill identified gaps in the skills and recommend a suitable number of qualified personnel to run the system.

Then, the hypothesis $\mathbf{H} \mathbf{2}$ is accepted. Other studies conducted in connection with the hypothesis mentioned above $(\mathrm{H} 2)$ have already studied capacity building in Pakistan's banking sector, and found that the indefinite reinforcement of $56 \%$ [40]. Wanyama et al. [51] research the relationship between employee efficiency and capacity building for commercial banks in Kenya and the conclusions signify the positive relationship between capacity building and employee productivity with $(\beta=0.52, p<0.05)$.

With the comparison of empirical research, our study suggests that such claims are not convincing. Employee skills development, productivity and alignment of interest have a positive influence on organizational performance. Other studies conducted on the hypothesis $\mathbf{H 1}$ discussed above, such as for Pakistan's banking sector, the support of Oversight and Organizational Support to Professional Development (OSCD) had a negligible effect on the employee performance [52]. They found a positive $\beta$ value of 0.175 , which means that the independent variable contributes $17.74 \%$ to the employee's performance. The indefinite t-value of the independent variable is 1.774 , reflecting a lower involvement of management and OSCD in employee performance. Similarly, it indicates that the p-value is 0.1 levels, which is also less significant, above the standard value of 0.05 . On the other hand, the research results 
of Saleem et al. [53] showed the effect of manager/ supervisor support on the employee's performance. They found that $(\beta=0.53, p<0.05, t<3.767)$ and showed that the manager support and employee performance have a positive relationship with another. Besides, Noe [54] held this position and proved that manager support had a significant effect on an employee's developmental behaviour. The Smart PLS analysis suggests that development manager support $(\beta=0.023, p<0.766)$ has an insignificant but positive effect on employee development behaviour. Employee retention as a moderator in the relationship between managers is consistent with employee performance. The results $(\beta=0.38, p<0.007, t<2.718)$ show that retention of employees moderated the effect of the relationship between manager support and employee performance. So, hypothesis $\mathbf{H 1}$ is not supported. The Smart PLS analysis suggests that development alignment of interest $(\beta=0.627, p>0.000)$ has a significant and positive effect on employee development behaviour. Employee retention as a moderator in the relationship between the alignments of interest is consistent with employee performance. The results $(\beta=0.052, p<0.006, t<2.14)$ show that retention of employees moderated the effect on the relationship between the alignment of interest and employee performance and hypothesis H3 is supported. In support of Hypothesis H3, Kwon et al. investigated the role of employee retention as a moderating relationship between the alignment of interest and employee performance, which has a significant and positive $(p<0.02)$ [55]. Alignment of interest is not merely used as a performance measure, but also for employee's satisfaction and reduces the turnover of the organization. In this context, Wright et al. [27] expresses that alignment of interest is not simply a performance measure but it shows the relationship and the level of contribution of an employee to corporate strategy.

\section{CONCLUSIONS}

This study engrossed in the alignment of interest, capacity building, manager support, employee retention and employee performance. Generally, the productivity of employees leads to progress in the textile sector. This study also includes the highlights of previous contributions to the factors that affect employee performance. Specifically, we focus on the alignment of interest and capacity building because the alignments of interest and employee skills development help to increase employee performance and productivity as approved by this research.

Additionally, this research focused on the role of manager support to employee performance and concludes that there is an insignificant impact of manager support on employee performance in the textile industry. According to our results, in the textile sector in Faisalabad, Pakistan, the relationship between the alignment of interest and employee performance in the presence of employee retention as a moderator is significant. Long-term employees have more interest in the organization such as shareholding and profit share and they are considered more loyal and concerned with the progress of the organization. So, its overall impact is positive on employee performance and provides opportunities for professional growth for their organizations.

\section{RECOMMENDATION}

Based on previous findings and conclusions, "it is recommended that alignment of interest, skill creation, and employee productivity be positively correlated with organizational performance". Therefore, companies need to plan and implement strategies that are in line with the objectives of a company and the interest of employees to improve the performance of employees. The size of the current study was small, future studies could clarify alignment of interest, capacity building and the effect of manager support in different occupational groups in a business environment is one of the major challenges facing the textile sector confronted. The main recommendation in retaining employees is that the textile sector should give the most important for the alignment of interest. Management should introduce employee benefit schemes to enhance the employee's interest. Shareholding and profit share to employees can also be considered. Moreover, capacity development and management support can create a sustainable competitive advantage over other key players. These aspects improve the efficiency of an employee. Hardworking employees ensure that companies succeed, and so they must be fully independent and allowed to take work decisions that produce better results. The importance of intellectual capital is highly recognized to improve employee performance. Currently, Pakistan's textile sector is likely to use its entire human capital. Where alignment of interest is so important for employees as well as a company but it is not in practice in the textile sector of Pakistan.

\section{LIMITATIONS AND FUTURE RESEARCH}

The interpretation of results has been done through cross-sectional data. Non-probability sampling technique is used for data collection versus probabilistic sampling which is considered more valid for generalizing the results. The small sample size also limits the generalization of results. Furthermore, the lack of collaboration among key agencies, non-leaders, training institutes and universities, it was difficult to collect accurate data from respondents. This study includes alignment of interest, capacity building and management support as key factors to improve employee performance, but there may be other factors that can affect the employee's performance. 


\section{REFERENCES}

[1] Frazis, H., Gittleman, M., Joyce, M., Correlates of Training: An Analysis Using Both Employer and Employee Characteristics, In: ILR Rev., 2000, 53, 3, 443-462

[2] Groot, R., van den Molen, P., Workshop on Capacity Building in Land Administration for Developing Countries, 2000

[3] Mastrangelo, A., Eddy, E.R., Lorenzet, S.J., The relationship between enduring leadership and organizational performance, In: Leadersh. Organ. Dev. J., 2014, 35, 7, 590-604

[4] Hennig-Thurau, T., Customer orientation of service employees: Its impact on customer satisfaction, commitment, and retention, In: Int. J. Serv. Ind. Manag., 2004, 15, 5, 460-478

[5] Campbell, J.P., Gasser, M.B., Oswald, F.L., The Substantive Nature of Job Performance Variability, 1996, 258-299

[6] Mathis, R.L., Jackson, J.H., Human Resource Management, 12th ed., 2009

[7] Islam, M.Z., Siengthai, S., Quality of work life and organizational performance: Empirical evidence from Dhaka Export Processing Zone, 2009

[8] Roodt, G., Rieger, H.S., Sempane, M.E., Job satisfaction in relation to organisational culture, In: SA J. Ind. Psychol., 2002, 28, 2, 23-30

[9] Wanyama, K.W., Mutsotso, S.N., Relationship between capacity building and employee productivity on performance of commercial banks in Kenya, In: African J. Hist. Cult., 2010, 2, 5, 73-78

[10] Pfeffer, J., Seven Practices of Successful Organizations, In: Calif. Manage. Rev., 1998, 40, 2, 96-124

[11] Hughes, K.D., Exploring Motivation and Success Among Canadian Women Entrepreneurs, In: J. Small Bus. Entrep., 2006, 19, 2, 107-120

[12] Shabir Hyder, P., Lussier, R.N., Why Businesses Fail, In: J. Entrep. Manag. Sustain. Dev., 1983, 8, 1, 15-21

[13] Yukl, G.A., Becker, W.S., Effective Empowerment in Organizations, In: Organ. Manag. J., 2006, 3, 3, $210-231$

[14] Zhang, A.Y., Tsui, A.S., Song, L.J., Li, C., Jia, L., How do I trust thee? The employee-organization relationship, supervisory support, and middle manager trust in the organization, In: Hum. Resour. Manage., 2008, 47, 1, 111-132

[15] Turk, W., Manager or leader?, In: Defense AT\&L, 2007, 4

[16] Trinka, J.A., What's a manager to do?, In: Ind. Commer. Train., 2005, 37, 3, 154-159

[17] Scase, R., Goffee, R., Women in management: towards a research agenda, In: Int. J. Hum. Resour. Manag., 1990, 1, 1, 107-125

[18] Altinkurt, Y., Yilmaz, K., Relationship between School Administrators' Organizational Power Sources and Teachers' Organizational Citizenship Behaviors", In: Educational Sciences: Theory \& Practice, 2012, 12, 3, 1843-1852

[19] Fullan, M., The New Meaning of Educational Change, Teachers College Press, New York, 2007

[20] Al $\square$ Roubaie, A., Building indigenous knowledge capacity for development, In: World J. Sci. Technol. Sustain. Dev., 2010, 7, 2, 113-129

[21] Crotts, J.C., Ford, R.C., Heung, V.C.S., Ngai, E.W.T., Organizational alignment and hospitality firm performance, In: Int. J. Cult. Tour. Hosp. Res., 2009, 3, 1, 3-12

[22] Becker, B., Gerhart, B., The Impact of Human Resource Management on Organizational Performance: Progress and Prospects, In: Acad. Manag. J., 1996, 39, 4, 779-801

[23] Boswell, W., Aligning employees with the organization's strategic objectives: out of 'line of sight', out of mind, In: Int. J. Hum. Resour. Manag., 2006, 17, 9, 1489-1511

[24] Delery, J.E., Shaw, J.D., The strategic management of people in work organizations: Review, synthesis, and extension, 165-197

[25] Truss, C., Complexities and Controversies in Linking HRM with Organizational Outcomes, In: J. Manag. Stud., 2001, 38, 8, 1121-1149

[26] Wright, P.M., Boswell, W.R., Desegregating HRM: A Review and Synthesis of Micro and Macro Human Resource Management Research, In: J. Manage., 2002, 28, 3, 247-276

[27] Wright, P.M., McMahan, G.C., Theoretical Perspectives for Strategic Human Resource Management, In: J. Manage., 1992, 18, 2, 295-320

[28] Truckenbrodt, Y.B., The Relationship Between Leader-Member Exchange and Commitment and Organizational Citizenship Behavior, In: Acquis. Rev. Q., 2000, 233-244

[29] Steers, R.M., Antecedents and Outcomes of Organizational Commitment, In: Adm. Sci. Q., 1977, 22, 1, 46

[30] Gul, A., Sciences, H.-M., Zeb, J., Apcoms, D., Role of Capacity Development, Employee empowerment and Promotion on Employee Retention in the banking sector of Pakistan Sajjad Akbar, 2012

[31] Cappelli, P., A Market-Driven Approach to Retaining Talent, In: Harv. Bus. Rev., 2000, 78, 1, 103

[32] Cole, C.L., "Building Loyalty", Workforce, 2000, 44-48

[33] Östör, Á., Critical Events: An Anthropological Perspective on Contemporary India, In: Am. Ethnol., 1997, 24, 4, 951-953

[34] Barrett, A., O'Connell, P.J., Does Training Generally Work? The Returns to in-Company Training, In: ILR Rev., 2001, 54, 3, 647-662

[35] Thite, M., All that Glitters is not Gold: Employee Retention in Offshored Indian Information Technology Enabled Services, In: J. Organ. Comput. Electron. Commer., 2010, 20, 1, 7-22 
[36] Tan, H.H., Lim, A.K.H., Trust in Coworkers and Trust in Organizations, In: J. Psychol., 2009, 143, 1, 45-66

[37] Palomo, M., Beinart, H., Cooper, M.J., Development and validation of the Supervisory Relationship Questionnaire (SRQ) in UK trainee clinical psychologists, In: Br. J. Clin. Psychol., 2010, 49, 2, 131-149

[38] Frerk, C., et al., Difficult Airway Society 2015 guidelines for management of unanticipated difficult intubation in adults, In: Br. J. Anaesth., 2015, 115, 6, 827-848

[39] Gligor, D.M., Holcomb, M.C., Antecedents and Consequences of Supply Chain Agility: Establishing the Link to Firm Performance, In: J. Bus. Logist., 2012, 33, 4, 295-308

[40] Asiya, G., Akbar, S., Jan, Z., Role of Capacity Development, Employee empowerment and Promotion on Employee Retention in the banking sector of Pakistan, In: Int. J. Acad. Res. Bus. Soc. Sci., 2012, 2, 9, 284-300

[41] Quresh, T.M., Akbar, A., Khan, M.A., Sheikh, R.A., Hijazi, S.T., Do human resource management practices have an impact on financial performance of banks?, In: African journal of business management., 2010, 4, 7

[42] Henseler, J., Ringle, C.M., Sinkovics, R.R., The use of partial least squares path modeling in international marketing, 2009, 277-319

[43] Hair, J.F., Ringle, C.M., Sarstedt, M., PLS-SEM: Indeed a Silver Bullet, In: J. Mark. Theory Pract., 2011, 19, 2, 139-152

[44] Hair, J.F., Sarstedt, M., Hopkins, L., Kuppelwieser, V.G., Partial least squares structural equation modeling (PLS-SEM), In: Eur. Bus. Rev., 2014, 26, 2, 106-121

[45] Chin, W.W., How to Write Up and Report PLS Analyses, In: Handbook of Partial Least Squares, Berlin, Heidelberg: Springer Berlin Heidelberg, 2010, 655-690

[46] Kim, M.-K, Park, M.-C., Jeong, D.-H., The effects of customer satisfaction and switching barrier on customer loyalty in Korean mobile telecommunication services, In: Telecommunications Policy, 2004, 28, 2, 145-159

[47] Falk, R., Miller, N., A primer for soft modeling, 1992

[48] Guest, D.E., Human resource management and performance: a review and research agenda, In: Int. J. Hum. Resour. Manag., 1997, 8, 3, 263-276

[49] Asfaw, A.M., Argaw, M.D., Bayissa, G.L., The Impact of Training and Development on Employee Performance and Effectiveness: A Case Study of District Five Administration Office, Bole Sub-City, Addis Ababa, Ethiopia, In: Journal of Human Resource and Sustainability Studies, 2015, 3, 4, 188-202

[50] Fletcher, L., Alfes, K., Robinson, D., The relationship between perceived training and development and employee retention: the mediating role of work attitudes, In: Int. J. Hum. Resour. Manag., 2018, 29, 18, 2701-2728

[51] Wanyama, K.W., Mutsotso, S.N., Relationship between capacity building and employee productivity on performance of commercial banks in Kenya, In: African Journal of History and Culture, 2010, 2, 73-78

[52] Ahmad, T., Farrukh, F., Nazir, S., Capacity building boost employees performance, In: Ind. Commer. Train., 2015, 47, 2, 61-66

[53] Saleem, S., Sama, S., The impact of organizational support for career development and supervisory support on employee performance: An empirical study from Pakistani academic, European Journal of Business and Management, 2013, 5, 5

[54] Noe, R.A., Is career management related to employee development and performance?, In: J. Organ. Behav., 1996, $17,2,119-133$

[55] Kwon, K., Chung, K., Roh, H., Chadwick, C., Lawler, J.J., The moderating effects of organizational context on the relationship between voluntary turnover and organizational performance: Evidence from Korea, In: Hum. Resour. Manage., 2012, 51, 1, 47-70

Authors:

MUHAMMAD ASIM SHAHZAD ${ }^{1}$, DONG JUN¹, QANDEEL HASSAN², RANA AHSAN ZUBAIR ${ }^{3}$, TAHIR IQBAL ${ }^{4}$

${ }^{1}$ North China Electric Power University, School of Economics \& Management, 102206, Beijing, China

${ }^{2}$ National College of business administration \& Economics University, Department of Business Administration, Lahore, Pakistan

${ }^{3}$ Government College University Faisalabad, Department of Business Administration, Faisalabad, Pakistan

${ }^{4}$ Departamento de Dirección y Organización de Empresas

University of Zaragoza, Edificio Betancourt, Campus Rio Ebro, 50018 Zaragoza, Spain

e-mail: tahiriqbalm1@gmail.com

Corresponding author:

MUHAMMAD ASIM SHAHZAD

e-mail: asimshahzad59@yahoo.com 